\title{
A Tradicionális Kínai Medicina (TCM) növényi hatóanyagai
}

\section{Pallos József Péter}

Gyógynövénykutató Intézet Kft., 2011 Budakalász, Lupaszigeti út 4.

A TCM, azaz a Hagyományos Kínai Gyógyítás jellemzője, hogy kiterjedten, az egészség tekintetében nemcsak a gyógyszerek, hanem a diagnosztika, a gyógymódok és a betegségmegelőzés összességeként őrizte meg a keleti szemlélet, és a nézetek hagyományait.

$A z$ emberi fejlődéstörténet ívét szépen rajzolja fel a gyógyítás múvészete, melynek folyamatosan megújuló eszközkészlete a régi-új „ósdi” - mégis modern növényi hatóanyagokkal végzett gyógyítás.

A világban, de különösen Európában egyre nagyobb igény mutatkozik a TCM orvoslás és gyógyszerek iránt. Az Európai Gyógyszerkönyv számos TCM drog monográfiát vesz fel, vesz át, adaptál a Kínai Gyógyszerkönyvből. A ma érvényben lévő Európai Gyógyszerkönyvben közel 60 TCM drog szerepel, és külön munkacsoport dolgozik a további cikkelyek adaptációján.

Az Európai Unió piacaira nem kerülhet gyógyszer, növényi gyógyszer, drog, kivonat, hatóanyag vagy készítmény a jogszabályokban meghatározott vizsgálatok, és minőségbiztosítási felszabadítás nélkül, amelyet csak hatóságilag engedélyezett gyártó és/vagy vizsgáló helyek végezhetnek el.

Az előadás célja egy átfogó kép kialakítása az Európai Gyógyszerkönyvben szereplő és a tradicionális kínai gyógyításban használatos gyógynövények minőségi szabályozásáról, ami Európában már szinte nem a jövő, hanem a jelen. 